\title{
Recent advances in adaptive thermogenesis: potential implications for the treatment of obesity.
}

Citation for published version (APA):

Wijers, S. L., Saris, W. H., \& van Marken Lichtenbelt, W. (2009). Recent advances in adaptive thermogenesis: potential implications for the treatment of obesity. Obesity Reviews, 10(2), 218-226. https://doi.org/10.1111/j.1467-789X.2008.00538.x

Document status and date:

Published: 01/01/2009

DOI:

10.1111/j.1467-789X.2008.00538.x

Document Version:

Publisher's PDF, also known as Version of record

Document license:

Taverne

Please check the document version of this publication:

- A submitted manuscript is the version of the article upon submission and before peer-review. There can be important differences between the submitted version and the official published version of record.

People interested in the research are advised to contact the author for the final version of the publication, or visit the DOI to the publisher's website.

- The final author version and the galley proof are versions of the publication after peer review.

- The final published version features the final layout of the paper including the volume, issue and page numbers.

Link to publication

\footnotetext{
General rights rights.

- You may freely distribute the URL identifying the publication in the public portal. please follow below link for the End User Agreement:

www.umlib.nl/taverne-license

Take down policy

If you believe that this document breaches copyright please contact us at:

repository@maastrichtuniversity.nl

providing details and we will investigate your claim.
}

Copyright and moral rights for the publications made accessible in the public portal are retained by the authors and/or other copyright owners and it is a condition of accessing publications that users recognise and abide by the legal requirements associated with these

- Users may download and print one copy of any publication from the public portal for the purpose of private study or research.

- You may not further distribute the material or use it for any profit-making activity or commercial gain

If the publication is distributed under the terms of Article $25 \mathrm{fa}$ of the Dutch Copyright Act, indicated by the "Taverne" license above, 


\title{
Obesity Management
}

\section{Recent advances in adaptive thermogenesis: potential implications for the treatment of obesity}

\author{
S. L. J. Wijers, W. H. M. Saris and W. D. van Marken Lichtenbelt
}

Department of Human Biology, Nutrition and Toxicology Research Institute Maastricht, Maastricht University, Maastricht, the Netherlands

Received 16 July 2008; revised 21 September 2008; accepted 29 September 2008

Address for correspondence: Sander Wijers, Department of Human Biology, Maastricht University, PO Box 616, NL-6200 MD, Maastricht, the Netherlands. E-mail: s.wijers@hb.unimaas.nl

\begin{abstract}
Summary
Large inter-individual differences in cold-induced (non-shivering) and dietinduced adaptive thermogenesis exist in animals and humans. These differences in energy expenditure can have a large impact on long-term energy balance and thus body weight (when other factors remain stable). Therefore, the level of adaptive thermogenesis might relate to the susceptibility to obesity; efforts to increase adaptive thermogenesis might be used to treat obesity. In small mammals, the main process involved is mitochondrial uncoupling in brown adipose tissue (BAT), which is regulated by the sympathetic nervous system. For a long time, it was assumed that mitochondrial uncoupling is not a major physiological contributor to adaptive thermogenesis in adult humans. However, several studies conducted in recent years suggest that mitochondrial uncoupling in BAT and skeletal muscle tissue in adult humans can be physiologically significant. Other mechanisms besides mitochondrial uncoupling that might be involved are futile calcium cycling, protein turnover and substrate cycling. In conjunction with recent advances on signal transduction studies, this knowledge makes manipulation of adaptive thermogenesis a more realistic option and thus a pharmacologically interesting target to treat obesity.
\end{abstract}

Keywords: Calcium cycling, mitochondrial uncoupling, protein turnover, substrate cycling.

obesity reviews (2009) 10, 218-226

\section{Background}

The fast growing prevalence of overweight and obesity in our society progressively affects public health. Obesity raises the risk of developing high blood pressure, diabetes type II and arteriosclerosis, all of which are risk factors for cardiovascular diseases. The problem of obesity has given a strong impulse towards metabolic studies. Small differences in energy expenditure might have large longterm effects on body weight (1). One of the suggested metabolic factors involved in the development of obesity is adaptive thermogenesis. It is defined as the regulated production of heat in response to environmental temperature or diet. It protects the organism from cold exposure and regulates energy balance (EB) after changes in diet
(2). Recently, it has been shown that the individual metabolic responses to both mild-cold exposure and overfeeding are related (3). Therefore, cold- and diet-induced adaptive thermogenesis is likely to share the same regulatory mechanism. Therefore, it is feasible to aim more research at metabolic reactions to cold exposure.

Adaptive thermogenesis in response to cold exposure can be divided in two types: shivering thermogenesis (ST) and non-shivering thermogenesis (NST). The underlying mechanisms of NST and diet-induced adaptive thermogenesis are not fully elucidated yet. In this review we focus on these processes.

First, we discuss the metabolic responses after cold exposure and overfeeding and its respective neuronal regulation. 
Thereafter, we describe the most likely potential mechanisms for adaptive thermogenesis.

\section{Cold exposure}

Back in the 1950s, it was already shown in rodents that oxygen consumption increased two- to fourfold after cold exposure (4). During daily cold exposure, shivering gradually decreased towards zero intensity in $20 \mathrm{~d}$, while no decrease in oxygen consumption was found $(5,6)$. This indicates the existence of NST. A few years later, similar results were found in man. During winter, when subjects were acclimatized to lower temperatures, energy expenditure increased about $25 \%$ upon cold exposure. After $10 \mathrm{~d}$ of cold exposure, shivering faded away, but energy expenditure remained elevated to the same level (7). This increase in energy expenditure during cold exposure without shivering can be considered to be the first proof of NST in humans.

The observed smaller amount of NST upon cold exposure in adult humans (compared with rodents) might be caused by the larger surface to volume ratio. Therefore, relatively less heat loss occurs with comparable core temperatures of approximately $37^{\circ} \mathrm{C}$. Human newborns are able to increase their energy expenditure more than twofold without shivering (8), an increase comparable to that in rodents.

Most studies on cold exposure in humans are carried out in severe cold, when shivering also occurs $(9,10)$. In these circumstances it is hard to make a distinction between ST and NST, as ST is superimposed over NST. However, before shivering starts, NST can be observed. During pre-shivering (room temperature of $15^{\circ} \mathrm{C}$ ), resting metabolic rate increased by $12 \%$ (range $-6 \%$ to $28 \%$ ) (11). Also, attenuation of NST using medications has been performed. Administering propranolol, a non-selective $\beta$-adrenergic receptor blocker decreased oxygen consumption after cold exposure (room temperature of $5^{\circ} \mathrm{C}$ ) with $26 \%$, whereas there were no differences in shivering intensity (12). As propranolol inhibits the NST response (see chapter regulation), the decrease in energy expenditure is comparable to the amount of NST in the non-blocked status. In conclusion, these studies showed evidence for the existence of NST in adult humans.

In 1980, the same phenomenon has been described in humans after mild-cold exposure $\left(22\right.$ vs. $\left.28^{\circ} \mathrm{C}\right)$, without shivering. A mean increase in energy expenditure of $7 \%$ (range $2 \%$ to $12 \%$ ) was observed (13). Recently, some other studies of mild-cold exposure in human subjects have been performed. After mild-cold exposure of $60 \mathrm{~h}$, the total daily energy expenditure (TDEE) increased with $0.8 \mathrm{MJ} \mathrm{d}^{-1}$. As no shivering was registered, the full metabolic response could be explained by NST (14). In this study, the range in inter-individual variation of the increase in energy expenditure was large, $0.15-1.45 \mathrm{MJ} \mathrm{d}^{-1}$. In a comparable setting in the same lab, short-term $(3 \mathrm{~h})$ expo- sure to $15^{\circ} \mathrm{C}$ showed a significant increase in energy expenditure of $0.86 \mathrm{MJ} \mathrm{d}^{-1}$ (winter) and $0.57 \mathrm{MJ} \mathrm{d}^{-1}$ (summer), while the absence of shivering was confirmed by electromyogram measurements (15). The significant increase in metabolic rate in winter compared with summer conditions showed a cold acclimatization effect in the subjects. Considerable inter-individual differences in the metabolic response existed $\left(-0.23\right.$ to $\left.2.15 \mathrm{MJ} \mathrm{d}^{-1}\right)$, which remained throughout the seasons. Subjects that hardly increased their energy expenditure during summer were also low responders during winter and vice versa.

The above underlines that the metabolic response to cold exposure is an individual trait. A diminished energy expenditure is associated with an increase in body mass, while other factors remain fixed. Thus, low responders to cold might have a higher risk to gain weight than the subjects that have the ability to increase their energy expenditure, given an equal eating pattern. Claessens-van Ooijen et al. (16) recently showed that short-time mild-cold exposure $\left(60 \mathrm{~min}\right.$ at $\left.15^{\circ} \mathrm{C}\right)$ resulted in a smaller increase in energy expenditure in obese subjects compared with lean subjects $(6.4 \%$ vs. $17.2 \%)$. Keith et al. (17) proposed a possible relation between the recent increase in the prevalence of obesity and the fact that people nowadays live in a thermoneutral zone more often and, therefore, do not need to expend extra energy to achieve thermal comfort.

The most well-known mechanism to protect an organism against cold exposure is shivering. It can elicit increases in oxygen consumption up to five times basal metabolic rate (BMR) (18). Upon activation of the primary motor centre for shivering of the posterior hypothalamus, muscle fibres are starting to contract involuntarily (19). As no work is performed, heat is produced. However, as muscle fatigue occurs after longer periods of shivering, this is not an acclimatization mechanism for cold exposure but a protective mechanism to protect the organism from acute cold exposure. Therefore, shivering is not covered further in this review.

\section{Overfeeding and underfeeding}

After overfeeding, the same amount of excess energy intake does not invoke the same body weight gain in all people (20-25) (Table 1). In a classical study, Bouchard et al. (20) showed that overfeeding induced a weight gain of 4.3$13.3 \mathrm{~kg}$ after an excess energy intake of $353 \mathrm{MJ}$ in $100 \mathrm{~d}$. This implies a threefold range in energy cost of weight gain of $27-82 \mathrm{MJ} \mathrm{kg}^{-1}$.

An important aspect in these studies is the level of compliance, as is discussed extensively in the British Journal of Nutrition after publication of the paper by Lammert et al. (23). Most of the studies mentioned above (20,21,23-25) maximized compliance by supervision during meals. Vomiting could be the only way to surpass the supervision; it is 
Table 1 Weight gain ranges in a selection of overfeeding studies

\begin{tabular}{|c|c|c|c|c|c|}
\hline \multirow[t]{2}{*}{ Reference } & \multirow[t]{2}{*}{ Total excess energy intake } & \multicolumn{2}{|c|}{ Weight gain (kg) } & \multicolumn{2}{|c|}{ Cost of weight gain $\left(\mathrm{MJ} \mathrm{kg}^{-1}\right)$} \\
\hline & & Minimum & Maximum & Minimum & Maximum \\
\hline Bouchard et al. (20) & $353 \mathrm{MJ}(100 \mathrm{~d})$ & 4.3 & 13.3 & 27 & 82 \\
\hline Ravussin et al. (21) & $60 \%$ of EB $(9 d)$ & 2.2 & 3.8 & 12.6 & 27.6 \\
\hline Diaz et al. (22) & $50 \%$ of EB (42 d) & 5.0 & 10.5 & 20.4 & 35.2 \\
\hline \multirow[t]{2}{*}{ Lammert et al. (23) } & $105 \mathrm{MJ}(21 \mathrm{~d})^{\star}$ & -0.71 & 3.48 & 30 & $>105$ \\
\hline & $105 \mathrm{MJ}(21 \mathrm{~d})^{\dagger}$ & -0.73 & 3.17 & 33 & $>105$ \\
\hline Levine et al. (24) & $235 \mathrm{MJ}(56 \mathrm{~d})$ & 1.4 & 7.2 & 32.6 & 168 \\
\hline Joosen et al. (25) & $50 \%$ of EB (14 d) & 0.19 & 3.0 & 69 & $>207$ \\
\hline
\end{tabular}

*High fat feeding.

†High protein feeding.

EB, energy balance.

not likely that all non-gainers in these studies did mislead supervisors and vomited. Furthermore, an underestimation of baseline energy requirements could be involved. The studies measuring baseline energy expenditure $(21,24,25)$ ensured adequate weight maintenance energy intake levels, while studies assessing baseline energy requirements with questionnaires might have underestimated both baseline and overfeeding energy requirements $(20,22,23)$. As both categories of estimation for baseline energy expenditure give similar ranges of cost of weight gain, no effect of the estimation method on weight gain is expected.

As energy intake was standardized in the studies mentioned above, the differences in weight gain have to be caused by a difference in diet-induced thermogenesis (DIT), the increase in energy expenditure in response to food intake. DIT can be divided into two categories: obligatory and facultative thermogenesis. The obligatory part of DIT consists of all processes related to the digestion, absorption and processing of food. The facultative component enables 'wasting' of energy after a high caloric meal and prevents the storage of energy. The inter-individual differences in weight gain can be explained by the variability in potency of this facultative component. Stock's (26) reanalysis of several studies showed even larger inter-individual differences after diets unbalanced in protein content. The larger cost of weight gain in these unbalanced diets presumably protects for deficiencies in underrepresented essential proteins. When there are deficiencies for a certain protein, more energy is expended, in order to be able to consume more, thus also more proteins, without too much weight gain.

The link between energy expenditure and weight gain after overfeeding in humans has been shown by Levine et al. (24). In an out-patient study giving 4.2 MJ of excess energy per day for 8 weeks, the increase in TDEE (on average $2.28 \mathrm{MJ} \mathrm{d}^{-1}$ ) correlated negatively to the gain in fat mass $(r=-0.77)$. Recently, a mean increase of $0.76 \mathrm{MJ} \mathrm{d}^{-1}$ was shown after $3 \mathrm{~d}$ of $60 \%$ overfeeding in the confined space of a respiration chamber. The inter-individual differ- ences were large, ranging from -0.11 to $1.61 \mathrm{MJ} \mathrm{d}^{-1}$ (3). These differences in energy expenditure may correspond to the large inter-individual differences in weight gain after long-term overfeeding.

Reduction of adaptive thermogenesis can also be interpreted as a defensive, body mass saving, mechanism after underfeeding, as reviewed by Major et al. (27). Although over $80 \%$ of the variation in energy expenditure is explained by fat free mass, in several underfeeding studies (28-30) energy expenditure decreased below the expected value. In this case, adaptive thermogenesis prevents subjects from losing weight.

\section{Neuronal regulation}

Animal studies revealed that cold exposure, detected peripherally, is integrated by the hypothalamus, which activates the efferent pathways of the sympathetic nervous system (SNS). The SNS innervates (among others) thermogenic targets as the brown adipose tissue (BAT) and skeletal muscle (2). Several studies have shown that rodents with a blocked SNS or lacking catecholamines cannot maintain body temperature during cold exposure $(31,32)$. Also, administration of $\beta$-adrenergic receptor agonists caused an increase in energy expenditure (50-150\% increase, dependent on cold acclimation), comparable to the reaction to cold (31). Furthermore, storage of calories during normal caloric intake is increased after blocking the SNS (33).

In humans, comparable results have been found. Infusion of noradrenaline and adrenaline caused similar metabolic reactions as mild-cold exposure $(24 \%-36 \%$ increase in BMR) (34). The sympathetic control of adaptive thermogenesis is mediated by $\beta_{1}$ - and $\beta_{2}$-adrenoceptors, while energy expenditure is not affected by $\alpha_{1}$ - and $\alpha_{2}$-adrenoceptors (35). The role of $\beta_{3}$-adrenoceptors in energy expenditure regulation, except in BAT, is not clear yet (36). Propranolol administration (a non-selective 
$\beta$-adrenergic blocker) after glucose infusion induced a decrease in glucose-induced energy expenditure from 2.3 to 1.7 $\mathrm{MJ} \mathrm{d}^{-1}$ (37), which is comparable with the reaction to overfeeding.

\section{Tissues of interest}

Skeletal muscle is potentially one of the largest contributors to adaptive thermogenesis in humans. An adrenaline infusion, which caused an increase of $25 \%$ in whole body energy expenditure, stimulated the forearm muscle to consume $90 \%$ more oxygen. Extrapolated to the whole body, skeletal muscle would account for about $40 \%$ of adrenaline-induced thermogenesis (38). Controversially, noradrenaline infusion did not increase muscle blood flow and decreased the arteriovenous oxygen concentration difference over the muscle (39). However, the authors stated, in their discussion, that the muscle blood flow measuring technique they used had the tendency to underestimate blood flow, which might have affected their results greatly. Furthermore, local concentrations of noradrenaline might not be large enough to provoke the thermogenic effect.

Results from ingestion of ephedrine, which is a sympathomimetic compound acting both centrally and peripherally, are in line with the abovementioned adrenaline study. Ephedrine ingestion resulted in an average increase in leg oxygen consumption of $25 \%$. This accounted for an extrapolated contribution of the skeletal muscle tissue in ephedrine-induced thermogenesis of $50 \%$ (40). Finally, it has been shown that carbohydrates induced an increased adrenaline concentration, resulting in increased muscle thermogenesis (41). In conclusion, skeletal muscle tissue can be considered to be responsible for a large part of adaptive thermogenesis.

The BAT is the main contributor to adaptive thermogenesis in small mammals. Its relevance in adult humans has long been questioned. Despite the studies in the eighties showing a lack of a significant contribution of BAT (40), nowadays increasing evidence is found for a significant role of BAT in adult humans (42). Until now, no studies have been carried out quantifying the contribution of BAT to total adaptive thermogenesis.

Other tissues, such as the liver, which is highly metabolic active, might also contribute to adaptive thermogenesis in humans (2), although its contribution has not been quantified yet.

To gain more insight in tissues responsible for the increase in energy expenditure in adaptive thermogenesis, it is necessary to perform more rigorous tests. Combinations of measuring arteriovenous differences of oxygen or stable isotopes across tissues (43), micro-dialysis trials measuring metabolite concentrations in interstitial fluids of the tissues (44) and nuclear magnetic resonance spectroscopy (NMR) studies measuring selected substances with ${ }^{31} \mathrm{P},{ }^{1} \mathrm{H}$, or ${ }^{13} \mathrm{C}$ (e.g. glycogen) (45) will reveal more information (46). In combination with cold exposure tests or $\beta$-agonist administration, relative contributions of tissues for adaptive thermogenesis can be calculated.

\section{Postulated mechanism behind adaptive thermogenesis}

Most reactions in energy metabolism are tightly regulated. An amount of fuel gives stoichiometric amounts of NADH and $\mathrm{FADH}_{2}$. Fixed amounts of protons are pumped out of the mitochondrial matrix per molecule of $\mathrm{NADH}$ and $\mathrm{FADH}_{2}$ (10 and 6 respectively). ATP synthase needs three protons to convert ADP and Pi to ATP. Finally, fixed amounts of ATP are used for cellular work (47). However, efficiency of these processes is not $100 \%$, and energy is dissipated under normal baseline conditions (i.e. heat production). To enable an increase in thermogenesis following cold exposure without shivering, the efficiency of these processes has to be changed. Eligible processes for this energy dissipation are mitochondrial uncoupling, futile calcium cycling, protein turnover and substrate cycling. All processes will be discussed below.

\section{Mitochondrial uncoupling}

The most frequently studied mechanism is mitochondrial uncoupling in BAT, as it accounts for a major portion of thermogenesis after cold exposure in rodents (48). This uncoupling process is executed by uncoupling protein (UCP)-1, a unique inner-membrane protein for BAT. UCP-1 causes a reflux of protons into the mitochondrial matrix, bypassing the ATP synthase. Instead of using the energy stored in the proton gradient to produce ATP, which is the energy intermediate in the organism, heat is dissipated because of this so called proton leakage (48-50). UCP-1 knockout mice indeed cannot maintain body temperature in cold $(48,51)$.

Until recently, BAT was commonly thought to be scarcely present in adult humans, in spite of studies indicating BAT in adult, cold acclimatized humans (52,53). In the 1980s, Astrup et al. (40) performed an elegant study in which they first examined the presence of BAT in human necropsies. BAT was most abundant in the perirenal region $(92 \%$ of specimens contained brown adipocytes); smaller amounts were found in the cervical area $(40 \%)$ and the pericardial fat depot $(20 \%)$. They estimated the total content of BAT to be about $700 \mathrm{~g}$. After stimulating thermogenesis with ephedrine in man, the authors showed in the same publication that the perirenal BAT was not as active as the rat BAT. Their calculations revealed that the $700 \mathrm{~g}$ of BAT could only account for $14 \%$ of the total increase in energy expenditure. Nevertheless, only one BAT depot was investigated, assuming that all depots have the same activity. 
Similar results have been found by Cunningham et al. (54) by measuring BAT activity in isolated mitochondria from the same BAT depot. Following these studies, the attention for BAT in adult humans has been decreased.

However, several recent studies (55-57) that were performed with ${ }^{18} \mathrm{~F}$-2-fluoro-2-deoxyglucose-positronemission-tomography/computer-tomography (FDG-PET/ CT) showed active BAT-like depots when human subjects were exposed to cold (42). As no FDG-PET/CT measurements have been made with concomitantly taken BAT biopsies, it has not been shown directly that the active tissue identified as BAT-like depot is real UCP-1 containing BAT. However, the CT images revealed that the active sites are made up of adipose tissue, and several separate studies have shown UCP-1 containing BAT cells at active sites (42,58-61). With a combination of cold exposure, indirect calorimetry and FDG-PET/CT, the importance of these BAT-like depots for adaptive thermogenesis can potentially be quantified in vivo on whole body level, rather than at discrete locations using necropsy studies.

Recently, it has been shown that PRDM16, a protein abundant in BAT, is necessary for the activity of this thermogenic tissue (62). Transgenic expression of this gene in white fat precursors stimulated formation of brown fat cells, with UCP-1 expression and an increased uncoupled respiration (62). PRDM16 inhibits the formation of white adipose tissue and promotes the formation of BAT by binding to $\mathrm{C}$-terminal-binding protein- 1 and -2 and PPAR$\gamma$-coactivator- $1 \alpha$ and $-1 \beta$ (63). Therefore, it is likely that BAT can be recruited (even in adult humans) and can be a quantitatively important factor for adaptive thermogenesis. Testing for the abundance of this protein in (white) adipose tissue in human subjects can improve the insight in the presence in BAT. Surprisingly, PRDM16 has been shown to control a switch between brown fat and skeletal muscle cells (64), indicating that BAT is more similar to skeletal muscle tissue than to white adipose tissue (65). Expression of PRDM16 in myoblasts induced differentiation into brown adipocytes. UCP-1 containing BAT has been shown interspersed between muscle bundles of mice (66). In humans, brown adipocyte progenitors and UCP-1 mRNA have been identified in skeletal muscle tissue (67).

In humans four homologues of UCP-1 have been found that are abundant in other tissues than BAT. UCP-2 and -3 are more than 50\% identical to UCP-1 $(68,69)$ and do possess proton transport activity $(68,70-73)$. UCP-2 is abundant in several tissues: spleen, lung, stomach and white adipose tissue (74). Therefore, it might be playing a role in adaptive thermogenesis, although the effect is expected to be small (75). Also UCP-2 was not upregulated during mild-cold exposure, its predominant role is probably protection from reactive oxygen species (76). UCP-3 is an interesting target for research as it is predominantely expressed in skeletal muscle tissue. UCP-3 protein content was positively correlated to energy expenditure in humans. However, after $60 \mathrm{~h}$ of mild-cold exposure no increase in UCP-3 protein content could be found. UCP-3 mRNA was even down-regulated which would consequently lower the UCP-3 protein content (77). Alternative roles suggested for UCP-3 are not the regulation of energy metabolism but the handling of fatty acids in the mitochondria to prevent lipid-induced oxidative mitochondrial damage $(78,79)$ and the reduction of the proton gradient to prevent production of reactive oxygen species (80). UCP-4 and -5 (or BMCP-1) are brain-specific $(81,82)$ and have putative roles in the prevention of neuronal damage (83). Although expression of UCP-4 and UCP-5 was increased after cold exposure (84), they are not expected to play a role in adaptive thermogenesis as they are not expressed in peripheral tissues thought to be quantitatively important for adaptive thermogenesis (skeletal muscle, adipose tissue and liver).

Although the working mechanisms of mitochondrial uncoupling in skeletal muscle tissue are not yet fully understood, this does not imply that it is not a factor influencing adaptive thermogenesis. In a high resolution respirometry study, performed with permeabilized human skeletal muscle biopsies, it has been shown that during mild-cold exposure, state 4 (ATP synthase blocking by oligomycin) respiration, i.e. mitochondrial uncoupling, correlated significantly to the increase in energy expenditure (85). Changes in mitochondrial uncoupling in human skeletal muscle tissue have been shown before after endurance training (86) and triiodothyronine administration (87).

In conclusion, both UCP-1 mediated uncoupling in BAT and non-UCP-1 mediated uncoupling in skeletal muscle are candidate working mechanisms for adaptive thermogenesis.

\section{Futile calcium cycling}

Some fish living in cold environments (e.g. marlin and tuna) have an organ functioning specifically to dissipate heat. This organ warms muscle, viscera, brain and eyes (88). This organ does not have any UCP, as in BAT (89). The heater organ in fish is a derivative of muscle tissue and contains an extensive sarcoplasmic reticulum (SR) and T-tubule network. It lacks the contractile elements of the muscle tissue. SR calcium release channels, controlled by Ryanodine receptors (Ryr), cause a flow of $\mathrm{Ca}^{2+}$ out of the SR, triggered by acetylcholine receptors. The balance in calcium concentrations has to be corrected by an ATPdriven calcium pumping mechanism (Serca-1, sarco/ endoplasmic reticulum $\mathrm{Ca}^{2+}$-ATPase) (89). As Serca-1 uses ATP, which is not used for performing work, energy is dissipated in this futile cycle. The same mechanism has been found in humans suffering of malignant hyperthermia. Ryr-1 of these patients is more sensitive to several anaesthetic agents, leading to an outflow of $\mathrm{Ca}^{2+}$ out of the 
SR, resulting in an compensatory ATP-driven influx, which produces excessive heat (90). In obese mice, it has been demonstrated that calcium cycling can be triggered with a selective CB1 (cannabinoid receptor 1) antagonist, with as a result increased energy expenditure and, consequently, weight loss (91). Cold exposure in UCP-1 deficient mice showed an increase in Serca-2a expression, which enabled a calcium cycling induced rise in energy expenditure (92). In rats, underfeeding resulted in a decrease in calcium cycling (compared with an EB condition), implicating that this inhibition served as an energy saving mechanism (93). Although no human data are available, calcium cycling is one of the eligible mechanisms for adaptive thermogenesis in humans.

\section{Protein turnover}

Protein turnover is defined as degradation of proteins into amino acids and resynthesis of new proteins. It is responsible for a large part of the energy expenditure in an organism, $15-20 \%$ of BMR (94). Most tissues do exhibit protein turnover, specifically the skeletal muscle tissue $(25 \%$ of total protein turnover), liver $(24 \%)$, skin $(18 \%)$ and small intestine $(15 \%)(94)$. Although the skeletal muscle has a slower protein turnover than the small intestine, it is still the major contributor because of its large tissue mass. As skeletal muscle and liver possess the largest adaptive thermogenesis capacity in humans, protein turnover could be a contributor to this process. However, studies in rats $(95,96)$ and calves (97) did not find any increase in protein turnover upon cold exposure. After short-time cold exposure, protein synthesis even decreased. It is postulated that this is a mechanism for the organism to decrease lean body mass and herewith, BMR, to save energy under these harsh conditions (95).

On the other hand, it has been shown in humans after carbohydrate overfeeding that protein turnover increased by $12 \%(98)$. As inter-individual differences were large $(5-25 \%$ increase in protein turnover), part of the differences in adaptive thermogenesis might be explained by this mechanism. Therefore, protein turnover might be quantitatively important, although no data is available on energy expenditure level.

\section{Substrate cycling with fatty acids}

Substrate cycling with fatty acids has been observed in patients after severe burn injury (99). In these patients, energy expenditure increased largely because of fatty acid cycling, next to the increase in protein turnover. In triglyceride-fatty acid cycling, fatty acids are released during lipolysis and subsequently re-esterified rather than oxidized (100). For both reactions different enzymes and ATP are used in a futile way. Recently it was discovered in animals that substrate cycling between de novo lipogenesis and lipid oxidation is stimulated by leptin, causing an increase in energy expenditure $(101,102)$. It has also been shown in humans that mild-cold exposure increased fatty acid cycling (103). Upon starvation, it has been shown in an animal model that fatty acid cycling decreased, regulated by SCD1 (104). Therefore, it is feasible that fatty acid cycling does contribute to adaptive thermogenesis in humans. Several other substrate cycles exist, like the glucose/glycogen cycle, although they are not covered in this review, they may also affect adaptive thermogenesis.

\section{Conclusions}

Several mechanisms have the potential to contribute to adaptive thermogenesis in man. First, mitochondrial uncoupling in brown adipose fat tissue could be important, as increasing evidence arises that brown fat cells are present in adult humans and can be activated by cold exposure. Second, it has been shown that mitochondrial uncoupling plays a metabolic significant role in skeletal muscle tissue. This can be due to mitochondrial uncoupling in muscle fibres, to the possible switch of muscle tissue into brown fat or to another mechanism not elucidated yet. Furthermore, fatty acid cycling is also a promising target for future research, as it has been shown that it is increased by cold exposure in humans. As an increase in calcium cycling after cold exposure has not been measured in humans yet, it is still elusive if it has any influence in humans. Protein turnover is not found to be altered during cold exposure, although it increases during overfeeding, with large inter-individual differences. Therefore, this process could be of importance in diet-induced adaptive thermogenesis.

Although these mechanisms are potential contributors to adaptive thermogenesis, more research is needed to quantify their influence. Arteriovenous concentration difference, micro-dialysis and NMR studies in combination with cold exposure tests could reveal more tissues of interest and their relative contribution. Mitochondrial uncoupling in BAT can be investigated further with cold exposure tests in combination with PET/CT and PRDM16 measurements. Human mild-cold exposure tests measuring energy expenditure in combination with pharmacologically blocking or stimulating processes like calcium cycling, fatty acid cycling and protein turnover will give more insight in the relative contribution of these processes for adaptive thermogenesis. Furthermore, long-term cold acclimation tests could reveal whether uncoupling capacity can be increased. When more knowledge has been achieved, these mechanisms can be used for new strategies to prevent obesity, as they are all capable of increasing energy expenditure and, therefore, controlling long-term EB and body weight. 


\section{Conflict of Interest Statement}

No conflict of interest was declared.

\section{References}

1. Christiansen E, Garby L. Prediction of body weight changes caused by changes in energy balance. Eur J Clin Invest 2002; 32: 826-830.

2. Lowell BB, Spiegelman BM. Towards a molecular understanding of adaptive thermogenesis. Nature 2000; 404: 652-660.

3. Wijers SLJ, Saris WH, van Marken Lichtenbelt WD. Individual thermogenic responses to mild cold and overfeeding are closely related. J Clin Endocrinol Metab 2007; 92: 4299-4305.

4. Depocas F, Hart JS, Heroux O. Energy metabolism of the white rat after acclimation to warm and cold environments. J Appl Physiol 1957; 10: 393-397.

5. Davis TR, Johnston DR, Bell FC, Cremer BJ. Regulation of shivering and non-shivering heat production during acclimation of rats. Am J Physiol 1960; 198: 471-475.

6. Depocas F, Hart JS, Heroux O. Cold acclimation and the electromyogram of unanesthetized rats. J Appl Physiol 1956; 9: 404-408.

7. Davis TR. Chamber cold acclimatization in man. J Appl Physiol 1961; 16: 1011-1015.

8. Himms-Hagen J. Does thermoregulatory feeding occur in newborn infants? A novel view of the role of brown adipose tissue thermogenesis in control of food intake. Obes Res 1995; 3: 361369.

9. Tikuisis P, Bell DG, Jacobs I. Shivering onset, metabolic response, and convective heat transfer during cold air exposure. $J$ Appl Physiol 1991; 70: 1996-2002.

10. Jansky L, Janakova H, Ulicny B, Sramek P, Hosek V, Heller J, Parizkova J. Changes in thermal homeostasis in humans due to repeated cold water immersions. Pflugers Arch 1996; 432: 368372.

11. van Ooijen AM, van Marken Lichtenbelt WD, van Steenhoven AA, Westerterp KR. Cold-induced heat production preceding shivering. Br J Nutr 2005; 93: 387-391.

12. Paolone VJ, Paolone AM. Thermogenesis during rest and exercise in cold air. Can J Physiol Pharmacol 1995; 73: 1149-1153. 13. Dauncey MJ. Influence of mild cold on $24 \mathrm{~h}$ energy expenditure, resting metabolism and diet-induced thermogenesis. $\mathrm{Br} J$ Nutr 1981; 45: 257-267.

14. van Marken Lichtenbelt WD, Schrauwen P, van De Kerckhove $\mathrm{S}$, Westerterp-Plantenga MS. Individual variation in body temperature and energy expenditure in response to mild cold. Am J Physiol Endocrinol Metab 2002; 282: E1077-E1083.

15. van Ooijen AM, van Marken Lichtenbelt WD, van Steenhoven AA, Westerterp KR. Seasonal changes in metabolic and temperature responses to cold air in humans. Physiol Behav 2004; 82: $545-553$.

16. Claessens-van Ooijen AM, Westerterp KR, Wouters L, Schoffelen PF, van Steenhoven AA, van Marken Lichtenbelt WD. Heat production and body temperature during cooling and rewarming in overweight and lean men. Obesity (Silver Spring) 2006; 14: 1914-1920.

17. Keith SW, Redden DT, Katzmarzyk PT, Boggiano MM, Hanlon EC, Benca RM, Ruden D, Pietrobelli A, Barger JL, Fontaine KR, Wang C, Aronne LJ, Wright SM, Baskin M, Dhurandhar NV, Lijoi MC, Grilo CM, DeLuca M, Westfall AO, Allison DB. Putative contributors to the secular increase in obesity: exploring the roads less traveled. Int J Obes (Lond) 2006; 30: 1585-1594.
18. Eyolfson DA, Tikuisis P, Xu X, Weseen G, Giesbrecht GG. Measurement and prediction of peak shivering intensity in humans. Eur J Appl Physiol 2001; 84: 100-106.

19. Guyton AC, Hall JE. Textbook of Medical Physiology, 11th edn. Elsevier: Philadelphia, PA, 2006.

20. Bouchard C, Tremblay A, Despres JP, Nadeau A, Lupien PJ, Theriault G, Dussault J, Moorjani S, Pinault S, Fournier G. The response to long-term overfeeding in identical twins. N Engl J Med 1990; 322: 1477-1482.

21. Ravussin E, Schutz Y, Acheson KJ, Dusmet M, Bourquin L, Jequier E. Short-term, mixed-diet overfeeding in man: no evidence for 'luxuskonsumption. Am J Physiol 1985; 249: E470-E477.

22. Diaz EO, Prentice AM, Goldberg GR, Murgatroyd PR, Coward WA. Metabolic response to experimental overfeeding in lean and overweight healthy volunteers. Am J Clin Nutr 1992; 56: 641-655.

23. Lammert O, Grunnet N, Faber P, Bjornsbo KS, Dich J, Larsen LO, Neese RA, Hellerstein MK, Quistorff B. Effects of isoenergetic overfeeding of either carbohydrate or fat in young men. Br J Nutr 2000; 84: 233-245.

24. Levine JA, Eberhardt NL, Jensen MD. Role of nonexercise activity thermogenesis in resistance to fat gain in humans. Science 1999; 283: 212-214.

25. Joosen AM, Bakker AH, Westerterp KR. Metabolic efficiency and energy expenditure during short-term overfeeding. Physio Behav 2005; 85: 593-597.

26. Stock MJ. Gluttony and thermogenesis revisited. Int J Obes Relat Metab Disord 1999; 23: 1105-1117.

27. Major GC, Doucet E, Trayhurn P, Astrup A, Tremblay A. Clinical significance of adaptive thermogenesis. Int J Obes (Lond) 2007; 31: 204-212.

28. Weyer C, Walford RL, Harper IT, Milner M, MacCallum T, Tataranni PA, Ravussin E. Energy metabolism after 2 years of energy restriction: the biosphere 2 experiment. Am J Clin Nutr 2000; 72: 946-953.

29. Leibel RL, Rosenbaum M, Hirsch J. Changes in energy expenditure resulting from altered body weight. N Engl J Med 1995; 332: 621-628.

30. Doucet E, Imbeault P, St-, Pierre S, Almeras N, Mauriege P, Despres JP, Bouchard C, Tremblay A. Greater than predicted decrease in energy expenditure during exercise after body weight loss in obese men. Clin Sci (Lond) 2003; 105: 89-95.

31. Landsberg L, Saville ME, Young JB. Sympathoadrenal system and regulation of thermogenesis. Am J Physiol 1984; 247: E181E189.

32. Thomas SA, Palmiter RD. Thermoregulatory and metabolic phenotypes of mice lacking noradrenaline and adrenaline. Nature 1997; 387: 94-97.

33. Himms-Hagen J. Brown adipose tissue thermogenesis and obesity. Prog Lipid Res 1989; 28: 67-115.

34. Lesna I, Vybral S, Jansky L, Zeman V. Human nonshivering thermogenesis. J Therm Biol 1999; 24: 63-69.

35. Blaak EE, van Baak MA, Kempen KP, Saris WH. Role of alpha- and beta-adrenoceptors in sympathetically mediated thermogenesis. Am I Physiol 1993; 264: E11-E17.

36. van Baak MA. The peripheral sympathetic nervous system in human obesity. Obes Rev 2001; 2: 3-14.

37. Acheson K, Jequier E, Wahren J. Influence of beta-adrenergic blockade on glucose-induced thermogenesis in man. J Clin Invest 1983; 72: 981-986.

38. Simonsen L, Bulow J, Madsen J, Christensen NJ. Thermogenic response to epinephrine in the forearm and abdominal subcutaneous adipose tissue. Am J Physiol 1992; 263: E850E855. 
39. Kurpad AV, Khan K, Calder AG, Elia M. Muscle and whole body metabolism after norepinephrine. Am J Physiol 1994; 266: E877-E884.

40. Astrup A, Bulow J, Madsen J, Christensen NJ. Contribution of BAT and skeletal muscle to thermogenesis induced by ephedrine in man. Am J Physiol 1985; 248: E507-E515.

41. Astrup A, Bulow J, Christensen NJ, Madsen J, Quaade F. Facultative thermogenesis induced by carbohydrate: a skeletal muscle component mediated by epinephrine. Am J Physiol 1986; 250: E226-E229.

42. Nedergaard J, Bengtsson T, Cannon B. Unexpected evidence for active brown adipose tissue in adult humans. Am J Physiol Endocrinol Metab 2007; 293: E444-E452.

43. Enevoldsen LH, Simonsen L, Macdonald IA, Bulow J. The combined effects of exercise and food intake on adipose tissue and splanchnic metabolism. J Physiol 2004; 561: 871-882.

44. Schiffelers SL, Akkermans JA, Saris WH, Blaak EE. Lipolytic and nutritive blood flow response to beta-adrenoceptor stimulation in situ in subcutaneous abdominal adipose tissue in obese men. Int J Obes Relat Metab Disord 2003; 27: 227-231.

45. Petersen KF, Price TB, Bergeron R. Regulation of net hepatic glycogenolysis and gluconeogenesis during exercise: impact of type 1 diabetes. J Clin Endocrinol Metab 2004; 89: 4656-4664.

46. Magkos F, Sidossis LS. Methodological approaches to the study of metabolism across individual tissues in man. Curr Opin Clin Nutr Metab Care 2005; 8: 501-510.

47. Alberts B, Bray D, Lewis J, Raff M, Roberts K, Watson JD. Molecular Biology of the Cell, 3rd edn. Garland Publishing: New York, 1994.

48. Cannon B, Nedergaard J. Brown adipose tissue: function and physiological significance. Physiol Rev 2004; 84: 277-359.

49. Nicholls DG, Locke RM. Thermogenic mechanisms in brown fat. Physiol Rev 1984; 64: 1-64.

50. Klingenberg M, Huang SG. Structure and function of the uncoupling protein from brown adipose tissue. Biochim Biophys Acta 1999; 1415: 271-296.

51. Enerback S, Jacobsson A, Simpson EM, Guerra C, Yamashita H, Harper ME, Kozak LP. Mice lacking mitochondrial uncoupling protein are cold-sensitive but not obese. Nature 1997; 387: 90-94. 52. Heaton JM. The distribution of brown adipose tissue in the human. J Anat 1972; 112: 35-39.

53. Huttunen P, Hirvonen J, Kinnula V. The occurrence of brown adipose tissue in outdoor workers. Eur J Appl Physiol Occup Physiol 1981; 46: 339-345.

54. Cunningham S, Leslie P, Hopwood D, Illingworth P, Jung RT, Nicholls DG, Peden N, Rafael J, Rial E. The characterization and energetic potential of brown adipose tissue in man. Clin Sci (Lond) 1985; 69: 343-348.

55. Hany TF, Gharehpapagh E, Kamel EM, Buck A, HimmsHagen J, von Schulthess GK. Brown adipose tissue: a factor to consider in symmetrical tracer uptake in the neck and upper chest region. Eur J Nucl Med Mol Imaging 2002; 29: 1393-1398.

56. Truong MT, Erasmus JJ, Munden RF, Marom EM, Sabloff BS, Gladish GW, Podoloff DA, Macapinlac HA. Focal FDG uptake in mediastinal brown fat mimicking malignancy:v a potential pitfall resolved on PET/CT. AJR Am J Roentgenol 2004; 183 1127-1132.

57. Yeung HW, Grewal RK, Gonen M, Schoder H, Larson SM. Patterns of (18)F-FDG uptake in adipose tissue and muscle: a potential source of false-positives for PET. J Nucl Med 2003; 44: 1789-1796.

58. Bouillaud F, Combes-George M, Ricquier D. Mitochondria of adult human brown adipose tissue contain a 32000-Mr uncoupling protein. Biosci Rep 1983; 3: 775-780.
59. Bouillaud F, Villarroya F, Hentz E, Raimbault S, Cassard AM, Ricquier D. Detection of brown adipose tissue uncoupling protein mRNA in adult patients by a human genomic probe. Clin Sci (Lond) 1988; 75: 21-27.

60. Lean ME, James WP, Jennings G, Trayhurn P. Brown adipose tissue in patients with phaeochromocytoma. Int J Obes 1986; 10: 219-227.

61. Ricquier D, Nechad M, Mory G. Ultrastructural and biochemical characterization of human brown adipose tissue in pheochromocytoma. J Clin Endocrinol Metab 1982; 54: 803-807. 62. Seale P, Kajimura S, Yang W, Chin S, Rohas LM, Uldry M, Tavernier G, Langin D, Spiegelman BM. Transcriptional control of brown fat determination by PRDM16. Cell Metab 2007; 6: 38-54. 63. Kajimura S, Seale P, Tomaru T, Erdjument-Bromage H, Cooper MP, Ruas JL, Chin S, Tempst P, Lazar MA, Spiegelman $\mathrm{BM}$. Regulation of the brown and white fat gene programs through a PRDM16/CtBP transcriptional complex. Genes Dev 2008; 22: 1397-1409.

64. Seale P, Bjork B, Yang W, Kajimura S, Chin S, Kuang S, Scime A, Devarakonda S, Conroe HM, Erdjument-Bromage H, Tempst P, Rudnicki MA, Beier DR, Spiegelman BM. PRDM16 controls a brown fat/skeletal muscle switch. Nature 2008; 454: 961-967.

65. Cannon B, Nedergaard J. Developmental biology: Neither fat nor flesh. Nature 2008; 454: 947-948.

66. Almind K, Manieri M, Sivitz WI, Cinti S, Kahn CR. Ectopic brown adipose tissue in muscle provides a mechanism for differences in risk of metabolic syndrome in mice. Proc Natl Acad Sci USA 2007; 104: 2366-2371.

67. Crisan M, Casteilla L, Lehr L, Carmona M, PaoloniGiacobino A, Yap S, Sun B, Leger B, Logar A, Penicaud L, Schrauwen P, Cameron-Smith D, Paul RA, Peault B, Giacobino JPA. Reservoir of brown adipocyte progenitors in human skeletal muscle. Stem Cells 2008.

68. Fleury C, Neverova M, Collins S, Raimbault S, Champigny O, Levi-Meyrueis C, Bouillaud F, Seldin MF, Surwit RS, Ricquier D, Warden $\mathrm{CH}$. Uncoupling protein-2: a novel gene linked to obesity and hyperinsulinemia. Nat Genet 1997; 15: 269-272.

69. Boss O, Samec S, Paoloni-Giacobino A, Rossier C, Dulloo A, Seydoux J, Muzzin P, Giacobino JP. Uncoupling protein-3: a new member of the mitochondrial carrier family with tissue-specific expression. FEBS Lett 1997; 408: 39-42.

70. Zhang CY, Hagen T, Mootha VK, Slieker LJ, Lowell BB. Assessment of uncoupling activity of uncoupling protein 3 using a yeast heterologous expression system. FEBS Lett 1999; 449: 129_ 134.

71. Hinz W, Faller B, Gruninger S, Gazzotti P, Chiesi M. Recombinant human uncoupling protein-3 increases thermogenesis in yeast cells. FEBS Lett 1999; 448: 57-61.

72. Gong DW, He Y, Karas M, Reitman M. Uncoupling protein-3 is a mediator of thermogenesis regulated by thyroid hormone, beta3-adrenergic agonists, and leptin. J Biol Chem 1997; 272: 24129-24132.

73. Gimeno RE, Dembski M, Weng X, Deng N, Shyjan AW, Gimeno CJ, Iris F, Ellis SJ, Woolf EA, Tartaglia LA. Cloning and characterization of an uncoupling protein homolog: a potential molecular mediator of human thermogenesis. Diabetes 1997; 46: 900-906.

74. Pecqueur C, Alves-Guerra MC, Gelly C, Levi-Meyrueis C, Couplan E, Collins S, Ricquier D, Bouillaud F, Miroux B. Uncoupling protein 2 , in vivo distribution, induction upon oxidative stress, and evidence for translational regulation. J Biol Chem 2001; 276: 8705-8712.

75. Echtay KS. Mitochondrial uncoupling proteins - what is their physiological role? Free Radic Biol Med 2007; 43: 1351-1371. 
76. Ricquier D. Respiration uncoupling and metabolism in the control of energy expenditure. Proc Nutr Soc 2005; 64: 47-52. 77. Schrauwen P, Westerterp-Plantenga MS, Kornips E, Schaart G, van Marken Lichtenbelt WD. The effect of mild cold exposure on UCP3 mRNA expression and UCP3 protein content in humans. Int J Obes Relat Metab Disord 2002; 26: 450-457.

78. Schrauwen P, Hoeks J, Hesselink MK. Putative function and physiological relevance of the mitochondrial uncoupling protein-3: involvement in fatty acid metabolism? Prog Lipid Res 2006; 45: 17-41.

79. Himms-Hagen J, Harper ME. Physiological role of UCP3 may be export of fatty acids from mitochondria when fatty acid oxidation predominates: an hypothesis. Exp Biol Med (Maywood) 2001; 226: 78-84.

80. Echtay KS, Esteves TC, Pakay JL, Jekabsons MB, Lambert AJ, Portero-Otin M, Pamplona R, Vidal-Puig AJ, Wang S, Roebuck SJ, Brand MD. A signalling role for 4-hydroxy-2-nonenal in regulation of mitochondrial uncoupling. EMBO J 2003; 22: 4103-4110. 81. Mao W, Yu XX, Zhong A, Li W, Brush J, Sherwood SW, Adams SH, Pan G. UCP4, a novel brain-specific mitochondrial protein that reduces membrane potential in mammalian cells. FEBS Lett 1999; 443: 326-330.

82. Sanchis D, Fleury C, Chomiki N, Goubern M, Huang Q, Neverova M, Gregoire F, Easlick J, Raimbault S, Levi-Meyrueis C, Miroux B, Collins S, Seldin M, Richard D, Warden C, Bouillaud F, Ricquier D. BMCP1, a novel mitochondrial carrier with high expression in the central nervous system of humans and rodents, and respiration uncoupling activity in recombinant yeast. $J$ Biol Chem 1998; 273: 34611-34615.

83. Andrews ZB, Diano S, Horvath TL. Mitochondrial uncoupling proteins in the CNS: in support of function and survival. Nat Rev Neurosci 2005; 6: 829-840.

84. Yu XX, Mao W, Zhong A, Schow P, Brush J, Sherwood SW, Adams SH, Pan G. Characterization of novel UCP5/BMCP1 isoforms and differential regulation of UCP4 and UCP5 expression through dietary or temperature manipulation. FASEB J 2000; 14: 1611-1618.

85. Wijers SLJ, Schrauwen P, Saris WHM, van Marken Lichtenbelt WD. Human skeletal muscle mitochondrial uncoupling is associated with cold induced adaptive thermogenesis. PLOS ONE 2008; 3: e1777.

86. Fernstrom M, Tonkonogi M, Sahlin K. Effects of acute and chronic endurance exercise on mitochondrial uncoupling in human skeletal muscle. J Physiol 2004; 554: 755-763.

87. Lebon V, Dufour S, Petersen KF, Ren J, Jucker BM, Slezak LA, Cline GW, Rothman DL, Shulman GI. Effect of triiodothyronine on mitochondrial energy coupling in human skeletal muscle. J Clin Invest 2001; 108: 733-737.

88. Block BA. Thermogenesis in muscle. Annu Rev Physiol 1994; 56: 535-577.

89. O'Brien J, Block BA. Effects of Ca2+ on oxidative phosphorylation in mitochondria from the thermogenic organ of marlin. $J$ Exp Biol 1996; 199: 2679-2687.
90. Dulhunty AF, Beard NA, Pouliquin P, Kimura T. Novel regulators of $\mathrm{RyR} \mathrm{Ca} 2+$ release channels: insight into molecular changes in genetically-linked myopathies. J Muscle Res Cell Motil 2006; 27: 351-365.

91. Jbilo O, Ravinet-Trillou C, Arnone M, Buisson I, Bribes E, Peleraux A, Penarier G, Soubrie P, Le Fur G, Galiegue S, Casellas $\mathrm{P}$. The CB1 receptor antagonist rimonabant reverses the dietinduced obesity phenotype through the regulation of lipolysis and energy balance. FASEB J 2005; 19: 1567-1569.

92. Ukropec J, Anunciado RV, Ravussin Y, Kozak LP. Leptin is required for uncoupling protein-1-independent thermogenesis during cold stress. Endocrinology 2006; 147: 2468-2480.

93. O'Brien PJ, Shen H, Bissonette D, Jeejeebhoy KN. Effects of hypocaloric feeding and refeeding on myocardial $\mathrm{Ca}$ and ATP cycling in the rat. Mol Cell Biochem 1995; 142: 151-161.

94. Waterlow JC. Protein turnover with special reference to man. O J Exp Physiol 1984; 69: 409-438.

95. McAllister TA, Thompson JR, Samuels SE. Skeletal and cardiac muscle protein turnover during cold acclimation in young rats. Am J Physiol Regul Integr Comp Physiol 2000; 278: R705711.

96. Samuels SE, Thompson JR, Christopherson RJ. Skeletal and cardiac muscle protein turnover during short-term cold exposure and rewarming in young rats. Am J Physiol 1996; 270: R12311239.

97. Scott SL, Christopherson RJ, Thompson JR, Baracos VE. The effect of a cold environment on protein and energy metabolism in calves. Br J Nutr 1993; 69: 127-139.

98. Welle S, Matthews DE, Campbell RG, Nair KS. Stimulation of protein turnover by carbohydrate overfeeding in men. Am J Physiol 1989; 257: E413-E417.

99. Wolfe RR, Herndon DN, Jahoor F, Miyoshi H, Wolfe M. Effect of severe burn injury on substrate cycling by glucose and fatty acids. N Engl J Med 1987; 317: 403-408.

100. Wolfe RR, Klein S, Carraro F, Weber JM. Role of triglyceride-fatty acid cycle in controlling fat metabolism in humans during and after exercise. Am J Physiol 1990; 258: E382E389.

101. Solinas G, Summermatter S, Mainieri D, Gubler M, Pirola L, Wymann MP, Rusconi S, Montani JP, Seydoux J, Dulloo AG. The direct effect of leptin on skeletal muscle thermogenesis is mediated by substrate cycling between de novo lipogenesis and lipid oxidation. FEBS Lett 2004; 577: 539-544.

102. Reidy SP, Weber JM. Accelerated substrate cycling: a new energy-wasting role for leptin in vivo. Am J Physiol Endocrinol Metab 2002; 282: E312-E317.

103. Vallerand AL, Zamecnik J, Jones PJ, Jacobs I. Cold stress increases lipolysis, FFA Ra and TG/FFA cycling in humans. Aviat Space Environ Med 1999; 70: 42-50.

104. Mainieri D, Summermatter S, Seydoux J, Montani JP, Rusconi S, Russell AP, Boss O, Buchala AJ, Dulloo AG. A role for skeletal muscle stearoyl-CoA desaturase 1 in control of thermogenesis. FASEB J 2006; 20: 1751-1753. 